\title{
PENGARUH MODEL PEMBELAJARAN COURSE REVIEW HORAY TERHADAP KEAKTIFAN DAN HASIL BELAJAR MATEMATIKA
}

\author{
Windi Kristanti Ningrum ${ }^{1}$, Luh Putu Putrini Mahadewi ${ }^{2}$, I Gusti Ngurah Japa ${ }^{3}$ \\ 1,3 Jurusan Pendidikan Guru Sekolah Dasar, ${ }^{2}$ Jurusan TP, FIP \\ Universitas Pendidikan Ganesha \\ Singaraja, Indonesia \\ email : windi.kristanti@undiksha.ac.id ${ }^{1}$, pp-mahadewi@undiksha.ac.id ${ }^{2}$, \\ ngriapa pgsd@yahoo.co.id ${ }^{3}$
}

\begin{abstract}
Abstrak
Penelitian ini bertujuan untuk mengetahui pengaruh model pembelajaran Course Review Horay terhadap keaktifan belajar dan hasil belajar matematika. Penelitian ini merupakan penelitian eksperimen semu dengan desain post test only control group desain. Jumlah populasi siswa kelas $\mathrm{V}$ di Gugus 3 Kecamatan Kuta adalah 101 siswa, sedangkan jumlah sampel adalah 61 siswa yang dipilih secara random kelas. Sampel penelitian ini adalah kelas Va SD No. 2 Tuban dan SD No. 4 Tuban. Data keaktifan dan hasil belajar Matematika siswa dikumpulkan dengan metode observasi menggunakan instrumen lembar observasi keaktifan belajar dan metode tes menggunakan instrumen tes hasil belajar matematika. Teknik analisis yang digunakan adalah teknik analisis statistik deskriptif dan analisis manova. Diperoleh rata-rata keaktifan belajar di kelas eksperimen yaitu $=80,26$ dan kelas kontrol $=71,50$. Rata-rata yang diperoleh pada hasil belajar matematika di kelas eksperimen yaitu $=15,28$ dan kelas kontrol $=12,91$. Hasil analisis manova diperoleh $F_{\text {hit }}>F_{\text {tabel }}$ pada taraf signifikan $5 \%(26,59>3,16)$. Hasil penelitian tersebut menunjukan bahwa 1) terdapat pengaruh model pembelajaran Course Review Horay terhadap keaktifan belajar siswa pada siswa kelas V SD Gugus 3 Kecamatan Kuta tahun Ajaran 2017/2018 dan 2) terdapat pengaruh model pembelajaran Course Review Horay terhadap hasil belajar matematika siswa pada siswa kelas V SD Gugus 3 Kecamatan Kuta tahun Ajaran 2017/2018.
\end{abstract}

Kata kunci: Hasil Belajar, Keaktifan, Model CRH

\section{Abstract}

This research aimed to determine the effect of learning model of Course Review Horey of student's learning activities and of Mathemathic's study result. The type of this research was quasi experiment. The design of this research was Post-test only control group design. The total population of the students in Gugus III, Kuta Subdistrict were 101 students, and for the sample were 61 students which have been chosen in random class. The sample of this research was fifth grade students at SD No. 2 Tuban and SD No. 4 Tuban. The data of activities and Mathemathic's study result of students was obtained by observation method using observation sheet instrument of learning activity as well as test method by using the test results of the evaluation of student Mathemathic learning. The data analysis technique was used descriptive statistics analysis and manova. The average data of the student's learning activities in experiment class are $=80,26$ and control class $=71,50$. The average data of the Mathemathic's study result in experiment class are $=15,28$ and control class $=12,91$. Result of manova obtained $F_{\text {hit }}>F_{\text {tabel }}$ with significant level $5 \%(26,59>3,16)$. The result of this experiment is 1) there was effect of learning model of Course Review Horey of student's learning activities of the fifth grades elementary in Gugus III, Kuta subdistrict in the academic year 2017/2018. 2) there is effect of learning model of Course Review Horey of Mathemathic's study result of the fifth grades elementary in Gugus III, Kuta subdistrict in the academic year 2017/2018

Keywords: Study Result, Activities, Model Of CRH 


\section{Pendahuluan}

Pendidikan merupakan kebutuhan utama sebagai bekal manusia di kehidupannya, oleh karena itu sudah seharusnya pendidikan mendapatkan perhatian, dan menjadi prioritas oleh pemerintah, masyarakat, dan seluruh pelaku pendidikan. Pemerintah selalu berusaha untuk melakukan pembaharuan pendidikan. Pembahuruan pendidikan di Indonesia telah dilakukan pemerintah melalui beberapa usaha diantaranya adalah mengembangkan kurikulum di Indonesia. Pengembangan kurikulum ini bertujuan untuk membawa pendidikan Indonesia ke arah yang lebih baik, sehingga peserta didik bisa mendapatkan hasil yang maksimal. Disaat pemerintah sedang gencar melakukan upaya untuk meningkatkan kualitas pendidikan melalui pengembangan kurikulum, justru terlihat bahwa kualitas proses pembelajaran tidak sesuai dengan kurikulum yang telah disusun.

Hal ini dapat dilihat pada penerapan kurikulum yang telah diterapkan sejak tahun ajaran 2013/2014 yaitu kurikulum 2013. Proses pembelajaran pada kurikulum 2013 untuk semua jenjang mengharapkan pembelajaran yang terlaksana lebih berpusat pada siswa (Student center) sehingga siswa menjadi lebih aktif selama proses pembelajaran. Hal tersebut sejalan dengan pendapat Fontana (dalam Suwatra. 2015:2) yang menyatakan "belajar adalah suatu proses perubahan yang relatif tetap dalam perilaku individu sebagai hasil dari pengalaman". Namun, pada kenyataannya di lapangan aktifitas yang dilakukan siswa selama pembelajaran masih kurang, bahkan masih ada dalam beberapa pembelajaran siswa hanya cenderung diam dan mendengarkan penjelasan guru. Hal tersebut menyebabkan pengalaman yang didapatkan siswa selama proses pembelajaran masih kurang dan dapat mempengaruhi hasil belajar yang diperoleh siswa. Pernyataan tersebut sesuai dengan pendapat Kharida (2009) yang menyatakan bahwa "hasil belajar merupakan perubahan perilaku yang diperoleh siswa setelah mengalami aktivitas belajar".

Berdasarkan hasil wawancara yang telah dilakukan didapatkan informasi yang mengatakan bahwa di SD Gugus 3 Kecamatan Kuta hasil belajar matematika merupakan hasil belajar siswa yang paling rendah jika dibandingkan dengan mata pelajaran lainnya seperti mata pelajaran bahasa Indonesia, PKn, IPA, dan IPS. Matematika menurut Permana (2017) merupakan "suatu bahan kajian yang memiliki objek yang abstrak dan dibangun melalui proses penalaran deduktif, yaitu kebenaran suatu konsep diperoleh sebagai akibat logis dari kebenaran yang sebelumnya sudah diterima sehingga keterkaitan antara konsep dalam matematika sangat kuat dan jelas". Matematika sering dianggap sebagai mata pelajaran yang paling susah untuk dipahami oleh siswa SD jika dibandingkan dengan mata pelajar lain. Hal ini karena perkembangan kognitif siswa SD masih berada pada tahap operasional kontret, sehingga pada umumnya anak Sekolah Dasar akan menggalami kesulitan untuk memahami materi matematika yang bersifat abstrak. Berdasarkan data awal yang diperoleh dari hasil pencatatan dokumen di SD Gugus 3 Kecamatan Kuta, hasil belajar siswa mata pelajaran matematika kelas V SD gugus 3 Kecamatan Kuta masih ada beberapa siswa mendapatkan hasil belajar yang kurang memuaskan. Nilai rata-rata rapor semester I mata pelajaran matematika pada aspek kognitif dapat dilihat pada tabel berikut.

Tabel 1. Nilai Rata-Rata dan KKM Matematika Kelas V

\begin{tabular}{|c|c|c|c|c|c|c|}
\hline \multirow{2}{*}{ Nama Sekolah } & \multirow{2}{*}{ Kelas } & \multirow{2}{*}{ KKM } & \multirow{2}{*}{$\begin{array}{l}\text { Rata- } \\
\text { Rata } \\
\text { Kelas }\end{array}$} & \multirow{2}{*}{$\begin{array}{l}\text { Jumlah } \\
\text { Siswa }\end{array}$} & \multicolumn{2}{|c|}{ Persentase banyaknya siswa } \\
\hline & & & & & Di atas KKM & Di bawah KKM \\
\hline \multirow{3}{*}{ SD No. 1 Tuban } & $A$ & & 76,65 & 26 siswa & $96 \%$ & $4 \%$ \\
\hline & B & 72 & 75,70 & 27 siswa & $63 \%$ & $37 \%$ \\
\hline & $A$ & & 76,04 & 27 siswa & $93 \%$ & $7 \%$ \\
\hline \multirow[t]{2}{*}{ SD No. 2 Tuban } & $B$ & 68 & 73,48 & 29 siswa & $69 \%$ & $31 \%$ \\
\hline & C & & 73,52 & 27 siswa & $74 \%$ & $26 \%$ \\
\hline SD No, 4 Tuban & A & 73 & 75,25 & 32 siswa & $53 \%$ & $47 \%$ \\
\hline
\end{tabular}




\begin{tabular}{|c|c|c|c|c|c|c|}
\hline \multirow{2}{*}{ Nama Sekolah } & \multirow{2}{*}{ Kelas } & \multirow{2}{*}{ KKM } & \multirow{2}{*}{$\begin{array}{l}\text { Rata- } \\
\text { Rata } \\
\text { Kelas }\end{array}$} & \multirow{2}{*}{$\begin{array}{l}\text { Jumlah } \\
\text { Siswa }\end{array}$} & \multicolumn{2}{|c|}{ Persentase banyaknya siswa } \\
\hline & & & & & Di atas KKM & Di bawah KKM \\
\hline & $B$ & & 76,09 & 34 siswa & $97 \%$ & $3 \%$ \\
\hline & $\mathrm{C}$ & & 77,71 & 34 siswa & $97 \%$ & $3 \%$ \\
\hline SD No. 6 & $A$ & & 74,25 & 32 siswa & $94 \%$ & $6 \%$ \\
\hline Tuban & B & 70 & 75,39 & 33 siswa & $94 \%$ & $6 \%$ \\
\hline
\end{tabular}

(sumber: Dokumen Guru Wali Kelas V di Gugus 3 Kec. Kuta Tahun Pelajaran 2017/2018)

Bila dilihat secara keseluruhan dari 301 siswa kelas V di SD Gugus 3 Kecamatan Kuta terdapat $83 \%$ siswa atau sebanyak 251 siswa yang telah memenuhi KKM dan 17\% siswa atau sebanyak 50 siswa yang belum memenuhi KKM. Ketidak tuntasan hasil belajar tersebut dapat dipengaruhi oleh beberapa faktor, diantaranya guru yang kurang kreatif dalam menyampaikan materi yaitu belum menerapkan model pembelajaran yang inovatif sehingga siswa kurang aktif dalam mengikuti pembelajaran.

Permasalahan tersebut dapat diatasi dengan menciptakan pembelajaran yang menyenangkan dan merangsang minat siswa untuk lebih antusias aktif dalam proses pembelajaran. Model pembelajaran kooperatif dapat digunakan untuk meningkatkan aktivitas belajar siswa, sehingga siswa tidak merasa jenuh saat proses pembelajaran Salah satu model pembelajaran kooperatif yang dapat digunakan adalah model pembelajaran kooperatif tipe Course Review Horay.

Menurut Maryam (2016) Pelaksanaan pembelajaran dengan menerapan model pembelajaran kooperatif tipe $\mathrm{CRH}$, di mana aktivitas pembelajaran lebih banyak berpusat pada siswa dan guru hanya berperan sebagai penyampai informasi, fasilitator dan pembimbing yang mengurangi kebiasaan guru menerapkan pembelajaran konvensional. Shoimin (dalam Sari. 2017) menyatakan bahwa "model pembelajaran course review horay merupakan pembelajaran yang menguji pemahaman siswa menggunakan kotak yang diisi dengan soal dan diberi nomor untuk menuliskan jawabannya". Sedangkan Kurniasih dan Berlin (2015:81) menyatakan, "Model pembelajaran Course Review Horay merupakan suatu metode pembelajaran dengan pengujian pemahaman siswa menggunakan soal dimana jawaban soal dituliskan pada kartu atau kotak yang telah dilengkapi nomor dan untuk siswa atau kelompok yang mendapatkan jawaban atau tanda dari jawaban yang benar terlebih dahulu harus langsung berteriak "horay" atau menyanyikan yel-yel kelompoknya". Model pembelajaran ini dapat digunakan oleh guru untuk mengubah suasana pembelajaran di dalam kelas menjadi lebih menyenangkan, sehingga siswa merasa lebih tertarik dalam mengikuti proses pembelajaran. Menurut Sari (2015) Model pembelajaran CRH dapat menciptakan suasana kelas menjadi meriah dan menyenangkan karena setiap peserta didik yang sudah mendapat tanda (v) vertikal atau horizontal atau diagonal harus berteriak horay atau yel- yel lainnya. Menurut Triyanti (2018) dengan model pembelajaran Course Review Horay diharapkan siswa lebih semangat dalam belajar karena pembelajarannya tidak monoton diselingi sedikit hiburan sehingga suasana tidak menegangkan. Selain itu pembelajarannya menarik dan mendorong siswa untuk dapat terjun langsung ke dalamnya serta melatih kerjasama siswa dengan begitu penyampaian teori tidak akan monoton, sehingga dapat menarik perhatian siswa dan meningkatkan motivasi siswa untuk fokus pada pelajaran tersebut.

Menurut Kurniasih (2015) model pembelajaran Course Review Horay adalah model yang dapat menciptakan suasana kelas menjadi meriah dan menyenangkan karena setiap siswa yang dapat menjawab dengan benar maka siswa tersebut diwajibkan berteriak "hore" atau yel-yel yang disepakati. Menurut Nahar (2016) Model pembelajaran CRH merupakan suatu model pembelajaran untuk menguji pemahaman peserta didik dengan menggunakan strategi permainan, jika peserta didik dapat menjawab dengan benar maka peserta didik langsung berteriak "hore". Langkah-langkahmodelpembelajaran course review horay menurut Kurniasih dan Berlin (2016) yaitu sebagai berikut. (1) Guru menjelaskan tujuan pembelajaran, (2) Guru menyajikan atau mendemonstrasikan materi sesuai topik dengan 
tanya jawab, (3) Guru membagi siswa dalam kelompok, (4) Untuk menguji pemahaman siswa disuruh membuat kartu sesuai dengan kebutuhan dan diisi dengan nomor yang ditentukan guru, (5) Guru membaca soal secara acak dan siswa menuliskan jawabannya didalam kartu yang nomornya disebutkan guru, (6) Kelompok yang sudah selesai menjawab langsung menyampaikan jawabannya, (7) Kelompok lain mengulangi jawaban dari kelompok yang menjawab pertama, (8) Guru dan siswa mendiskusikan soal yang telah dijawab tadi, (9) Bagi kelompok yang benar, siswa memberi tanda check list $(\sqrt{ })$ dan langsung berteriak horay, (10) Nilai siswa dihitung dari jawaban yang benar dan yang banyak berteriak horay, (11) Guru memberikan reward yang memperoleh nilai tinggi, (12) Siswa dibantu guru menyimpulkan materi dan menutup pelajaran. Dengan pembelajaran yang demikian, konsep yang diperoleh siswa akan melekat dalam ingatannya. Siswapun akan merasakan proses belajar yang lebih bermakna dan dengan demikian keaktifan belajar dan hasil belajar siswa juga akan meningkat. Berdasarkan uraian tersebut, peneliti tertarik untuk melakukan sebuah penelitian berjudul "Pengaruh Model Pembelajaran Kooperatif Tipe Course Review Horay Terhadap Keaktifan dan Hasil Belajar Matematika Siswa Kelas V SD Semester II Tahun Ajaran 2017/2018 di Gugus 3 Kecamatan Kuta".

Berdasarkan uraian diatas maka tujuan dari penelitian ini adalah 1. Untuk mengetahui pengaruh model pembelajaran kooperatif tipe Course Review Horay terhadap keaktifan belajar siswa pada mata pelajaran matematika kelas V semester II tahun ajaran 2017/2018 di SD Gugus 3 Kecamatan Kuta. 2. untuk mengetahui pengaruh model pembelajaran kooperatif tipe Course Review Horay terhadap hasil belajar matematika siswa kelas V semester II tahun ajaran 2017/2018 di SD Gugus 3 Kecamatan Kuta.

\section{Metode}

Penelitian ini dilaksanakan di SD gugus 3 Kecamatan Kuta, yang terdiri dari empat sekolah yaitu, SD No. 1 Tuban, SD No, 2 Tuban, SD No. 4 Tuban, dan SD No. 5 Tuban. Penelitian ini dilaksanakan pada semester II tahun pelajaran 2017/2018. Penelitian ini termasuk jenis penelitian semu (quasi experiment). Desain eksperimen yang digunakan dalam penelitian ini adalah non-equivalent Control Group Desaign. Penelitian ini terdiri dari dua kelompok sampel yaitu kelompok eksperimen dan kelompok kontrol. Pemilihan sampel dalam penelitian ini dilakukan dengan cara teknik random sampling. Teknik group random sampling yang digunakan untuk menentukan kelas eksperimen dan kontrol dalam penelitian dengan cara undian, sehingga diperoleh kelas Vb SD No. 2 Tuban sebagai kelompok eksperimen dan kelas Va SD No. 4 Tuban sebagai kelas kontrol.

Penelitian ini melibatkan satu variabel bebas (model pembelajaran kooperatif tipe Course Review Horay), dan dua variabel terikat (keaktifan belajar dan hasil belajar). Data yang dikumpulkan dalam penelitian ini yaitu skor keaktifan belajar dan skor hasil belajar Matematika siswa kelas V SD. Metode pengumpulan data yang digunakan dalam penelitian ini adalah metode observasi dan tes. Instrument yang digunakan untuk memperoleh data keaktifan belajar dalam penelitian ini adalah instrumen observasi yang terdiri dari 6 indikator. Instrument yang digunakan untuk memperoleh data hasil belajar Matematika dalam penelitian ini adalah soal tes pilihan ganda sebayak 20 butir soal.

Analisis data yang digunakan adalah analisis statistik deskriptif, dan analisis statistik inferensial. Analisis statistik deskriptif digunakan untuk menghitung rata-rata, modus, median, standar deviasi, dan varian. Analisis statistik inferensial digunakan untuk menguji hipotesis penelitian. Pada penelitian ini analisis statistik inferensial yang digunakan adalah Multivariate Analysis of Variance (manova). 


\section{Hasil Dan Pembahasan}

Hasil analisis deskripsi data keaktifan belajar kelompok eksperimen dan kelompok kontrol disajikan pada tabel 2.

Tabel 2. Deskripsi Data Keaktifan Belajar

\begin{tabular}{ccc}
\hline Hasil Analisis & Kelompok Eksperimen & Kelompok Kontrol \\
\hline Mean & 80,26 & 71,50 \\
Median & 80,66 & 71 \\
Modus & 80,98 & 70,58 \\
Varians & 18,33 & 18,47 \\
Standar Deviasi & 4,28 & 4,30 \\
\hline
\end{tabular}

Berdasarkan Tabel 2, diketahui mean kelompok eksperimen lebih besar dari pada mean kelompok kontrol. Data keaktifan belajar siswa pada kelompok eksperimen dapat disajikan ke dalam kurva polygon seperti pada Gambar 1 berikut.

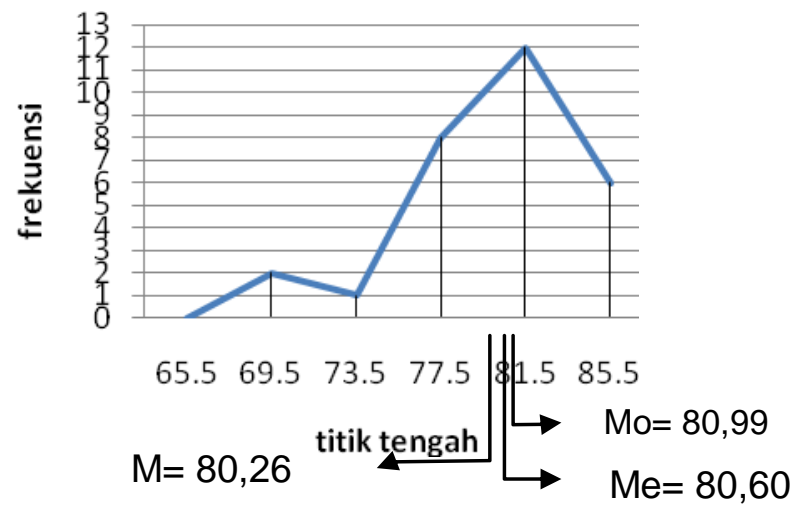

Gambar 1. Kurva Polygon Data Keaktifan Belajar Siswa Kelompok Eksperimen

Berdasarkan gambar. 1, diketahui modus lebih besar dari median, dan median lebih besar dari mean (Mo $>\mathrm{Md}>\mathrm{M}$ ). Hal tersebut menyatakan bahwa data keaktifan belajar kelompok eksperimen menunjukkan kurva juling negatifyang berarti sebagian besar skorcenderung tinggi. Skor rata-rata keaktifan belajar siswa kelompok eksperimen selanjutnya dikonversikan dengan menggunakan rata-rata ideal $\left(\mathrm{M}_{\mathrm{i}}\right)$ dan standar deviasi ideal $\left(S_{i}\right)$. Hasil analisis data diperoleh bahwa rata-rata keaktifan belajar kelompok eksperimen adalah 80,26. Jika dikonversikan ke dalam PAP Skala lima berada pada kategori baik. Selanjutnya mean, median, modus dari data keaktifan belajar kelompok kontrol, disajikan ke dalam bentuk kurva poligon seperti pada Gambar 2. 


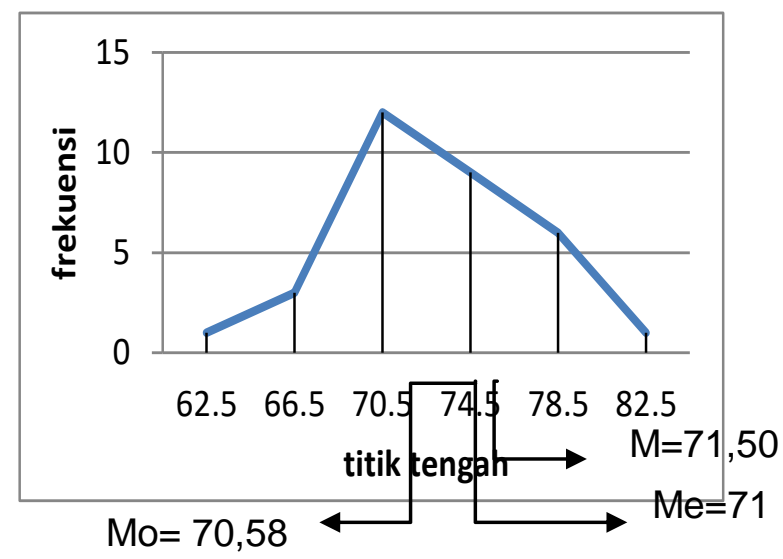

\section{Gambar 2. Kurva Polygon Data Keaktifan Belajar Siswa Kelompok kontrol}

Berdasarkan gambar. 2, diketahui rata-rata lebih besar dari median, dan median lebih besar dari modus $(\mathrm{M}>\mathrm{Md}>\mathrm{Mo}$ ). Hal tersebut menyatakan bahwa data keaktifan belajar kelompok kontrol menunjukkan kurva juling positifyang berarti sebagian besar skor cenderung rendah. Skor rata-rata keaktifan belajar siswa kelompok kontrol selanjutnya dikonversikan dengan menggunakan rata-rata ideal $\left(\mathrm{M}_{\mathrm{i}}\right)$ dan standar deviasi ideal $\left(\mathrm{SD}_{\mathrm{i}}\right)$. Hasil analisis data diperoleh bahwa rata-rata keaktifan belajar kelompok kontrol adalah 71,50. Jika dikonversikan ke dalam PAP Skala lima berada pada kategori cukup.

Hasil analisis deskripsi data keaktifan belajar kelompok eksperimen dan kelompok kontrol disajikan pada Tabel 3.

Tabel 3. Deskripsi Data Hasil Belajar Matematika

\begin{tabular}{lll}
\hline Hasil Analisis & Kelompok Eksperimen & Kelompok Kontrol \\
\hline Mean & 15,28 & 12,91 \\
Median & 15,85 & 13,30 \\
Modus & 17 & 13,50 \\
Varians & 12,82 & 10,80 \\
Standar Deviasi & 3,58 & 3,29 \\
\hline
\end{tabular}

Berdasarkan Tabel 3, diketahui mean data hasil belajar matematika kelompok eksperimen lebih besar dari pada mean kelompok kontrol. Data hasil belajar matematika siswa pada kelompok eksperimen dapat disajikan ke dalam kurva polygon seperti pada Gambar 3 berikut.

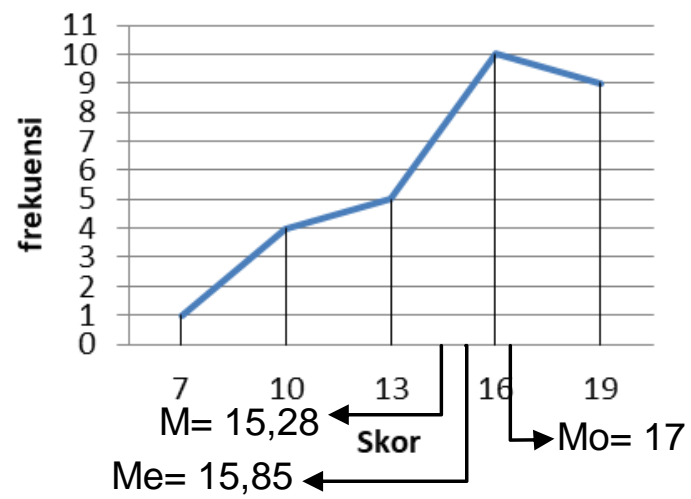

Gambar 3. Kurva Polygon Data Hasil Belajar Matematika Siswa Kelompok Eksperimen 
Berdasarkan gambar. 3, diketahui modus lebih besar dari median, dan median lebih besar dari mean (Mo > Md > M). Hal tersebut menyatakan bahwa data hasil belajar matematikakelompok eksperimen menunjukkan kurva juling negatifyang berarti sebagian besar skorcenderung tinggi. Skor rata-rata hasil belajar matematikasiswa kelompok eksperimen selanjutnya dikonversikan dengan menggunakan rata-rata ideal $\left(M_{i}\right)$ dan standar deviasi ideal $\left(\mathrm{SD}_{\mathrm{i}}\right)$. Hasil analisis data diperoleh bahwa rata-rata hasil belajar matematikakelompok eksperimen adalah 15,28. Jika dikonversikan ke dalam PAP Skala lima berada pada kategori sangat baik. Selanjutnya mean, median, modus dari data hasil belajar matematikakelompok kontrol, disajikan ke dalam bentuk kurva poligon seperti pada Gambar 4.

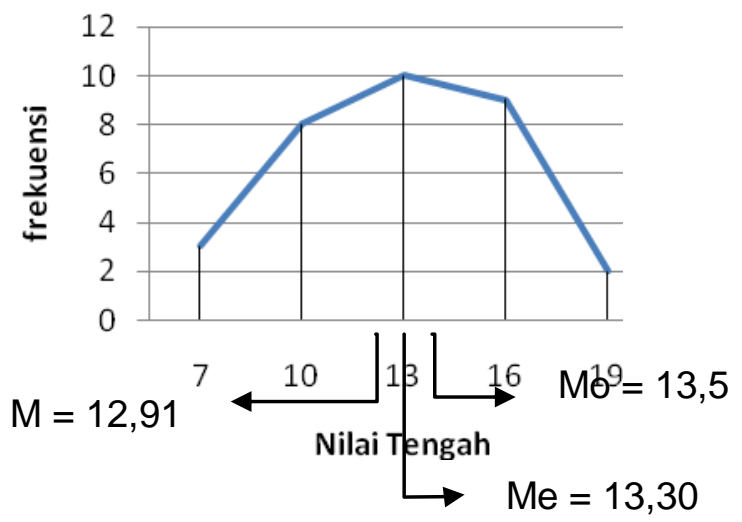

Gambar 4. Kurva Polygon Data Hasil Belajar Matematika Siswa Kelompok Kontrol

Berdasarkan gambar. 4, diketahui modus lebih besar dari median, dan median lebih besar dari mean (Mo $>\mathrm{Md}>\mathrm{M}$ ). Hal tersebut menyatakan bahwa data hasil belajar matematikakelompok kontrol menunjukkan kurva juling negatifyang berarti sebagian besar skorcenderung tinggi. Skor rata-rata hasil belajar matematikasiswa kelompok kontrol selanjutnya dikonversikan dengan menggunakan rata-rata ideal $\left(\mathrm{M}_{\mathrm{i}}\right)$ dan standar deviasi ideal $\left(S_{i}\right)$. Hasil analisis data diperoleh bahwa rata-rata hasil belajar matematikakelompok kontroladalah 12,91. Jika dikonversikan ke dalam PAP Skala lima berada pada kategori baik.

Setelah dilakukan analisis statistik deskriptif dilanjutkan dengan analisis statistik inferensial untuk menguji hipotesis. Analisis yang digunakan untuk menguji hipotesis pada penelitian ini adalah Multivariate Analysis of Variance (manova). Hasil perhitungan disajikan pada Tabel 4 berikut ini.

Tabel 4. Ringkasan Hasil Uji Hipotesis

\begin{tabular}{lllllll}
\hline $\begin{array}{l}\text { Kelompok Data Keaktifan } \\
\text { Belajar }\end{array}$ & $\mathbf{N}$ & $\mathbf{F}_{\text {hitung }}$ & $\mathbf{V}_{\mathbf{1}}$ & $\mathbf{V}_{\mathbf{2}}$ & $\mathbf{T}_{\text {tabel }}$ & Kesimpulan \\
\hline $\begin{array}{l}\text { Kelompok eksperimen } \\
\text { Kelompok kontrol }\end{array}$ & 29 & 26,68 & 2 & 58 & 3,16 & $\begin{array}{l}\mathrm{F}_{\text {hitung }}>\mathrm{F}_{\text {tabel }} \\
\mathrm{H}_{0} \text { ditolak }\end{array}$ \\
\hline
\end{tabular}

Berdasarkan analisis data diperoleh $\mathrm{F}_{\text {hitung }}$ sebesar 26,68 dibandingkan dengan $\mathrm{F}_{\text {tabel. }}$ Harga $F_{\text {tabel }}$ diperoleh dari tabel dengan $v_{1}=f(p)=2$ dan $v_{2}=\sum$ ni $-p-1=58$ pada taraf signifikansi $5 \%$ sebesar 3,16. Dari hasil analisis diperoleh $F_{\text {hitung }}>F_{\text {tabel }}(26,59>3,16)$, maka $\mathrm{H}_{0}$ ditolak dan $\mathrm{H}_{1}$ diterima. Dengan demikian, dapat disimpulkan bahwa terdapat pengaruh yang signifikan model pembelajaran kooperatif tipe Course Review Horay terhadap keaktifan belajar siswa pada mata pelajaran Matematika kelas V SD gugus 3 Kecamatan Kuta Tahun ajaran 2017/2018 dan terdapat pengaruh yang signifikan model pembelajaran kooperatif tipe Course Review Horay terhadap hasil belajar siswa pada mata pelajaran 
Matematika kelas V SD gugus 3 Kecamatan Kuta Tahun ajaran 2017/2018.

Terdapatnya pengaruh model pembelajaran kooperatif tipe Course Review Horay terhadap keaktifan belajar siswa dan hasil belajar siswa dipengaruhi oleh beberapa faktordiantaranya sebagai berikut.

Pertama, model pembelajaran kooperatif tipe Course Review Horay memberikan kesempatan kepada siswa untuk membentuk kelompok dan melakukan kegiatan diskusi dengan kelompoknya. Sesuai dengan pendapat Widyastuti (2016) yang menyatakan bahwa dengan membentuk kelompok dan berdiskusi siswa dapat berpartisipasi dalam kelompok sehingga mendapat ilmu baru dari setiap kegiatan yang dilakukan .

Kedua, keterlibatan guru sebagai fasilitator dalam pembelajaran dapat membuat suasana belajar menjadi lebih hidup. Hal ini dapat membentuk hubungan guru dengan siswa dan siswa dengan siswa, sehingga terjadi interaksi yang baik antara satu dengan lainnya dan menjadikan hubungan guru dengan siswa menjadi lebih dekat. Akibatnya, siswa menjadi lebih berani dan aktif dalam mengungkapkan pendapat maupun bertanya mengenai materi yang belum dimengerti.

Ketiga, kegiatan permainan memberikan pengalaman yang menyenangkan pada siswa. Melalui kegiatan tersebut, aktivitas siswa dalam pembelajaran berada pada suasana yang menyenangkan sehingga siswa tidak mudah bosan. Siswa pun dapat memahami materi dengan baik, dan berdampak pada hasil belajar siswa. Hal tersebut juga sesuai dengan hasil penelitian Lianto (2016) yang menyatakan bahwa "kegiatan bermain memberikan kesan yang menyenangkan pada diri siswa, hal ini dapat memupuk minat dan perhatian siswa untuk belajar, yang pada akhirnya dapat berpengaruh baik terhadap hasil belajar yang diperoleh siswa".

Keempat, pemberian penghargaan kepada kelompok berupa tanda checklist $(\sqrt{ })$ pada jawaban yang benar dan berteriak "hore" atau yel-yel lain yang telah disepakati dapat membuat suasana belajar menjadi menyenangkan, sehingga perhatian siswa dapat berpusat pada pembelajaran yang dilaksanakan. Hal ini menyebabkan siswa menjadi lebih aktif dan minat siswa dalam pembelajaran lebih besar, sehingga hasil belajar yang diperoleh siswa juga semakin meningkat.

Temuan penelitian tersebut sesuai dengan hasil penelitian sebelumnya yang dilakukan oleh Rita Supriani (2017) yang membuktikan bahwa model pembelajaran kooperatif tipe Course Review Horay berpengaruh terhadap keaktifan dan hasil belajar IPA. Penelitian serupa juga dilakukan oleh Indrieta Sari (2017) yang menemukan hasil bahwa model pembelajaran kooperatif tipe Course Review Horay berpengaruh tehadap aktivitas dan asil belajar kognitif IPA siswa kelas V.

\section{Simpulan dan Saran}

Berdasarkan rumusan masalah dan pembahasannya di atas, dapat disimpulkan bahwa terdapatpengaruh yang signifikan model pembelajaran kooperatif tipe Course Review Horay terhadap keaktifan belajar siswa pada mata pelajaran Matematika kelas V SD semester II tahun pelajaran 2017/2018 di Gugus 3 Kecamatan Kuta, dan terdapat pengaruh yang signifikan model pembelajaran kooperatif tipe Course Review Horay terhadap hasil belajar matematika siswa kelas V SD semester II tahun pelajaran 2017/2018 di Gugus 3 Kecamatan Kuta. Dapat dilihat pada hasil analisis manova yang menunjukkan bahwa $F_{\text {hitung }}=$ 26,59 Sedangkan $F_{\text {tabel }}$ untuk $v_{1}=2$ dan $v_{2}=58$ dengan taraf signifikan $5 \%=3,16$. Di samping itu, rata-rata skor keaktifa belajar kelompok eksperimen $(80,26$ ) lebih tinggi dibandingkan dengan rata-rata skor keaktifan belajar kelompok kontrol $(71,50)$. Begitu pula pada rata-rata skor hasil belajar matematika kelompok eksperimen $(15,28)$ lebih tinggi dibandingkan rata-rata skor hasil belajar matematika kelas kontrol $(12,91)$.

Dari hasil yang telah dipapar di atas maka dapat diketahui bahwa model pembelajaran kooperatif tipe Course Review Horay berpengaruh terhadap keaktifan belajar dan hasil belajar matematika siswa.Beberapa saran yang dapat diaujukan adalah sebagai berikut. Pertama, guru dapatmenjadikan model pembelajaran kooperatif tipe Course Review 
Horay sebagai alternatif untuk diterapkan dalam pembelajaran di kelas, sehingga siswa bisa menjadi lebih aktif dalam mengikuti pelajaran dan hasil belajar yang diperoleh lebih maksimal. Kedua, bagi siswa-siswa di sekolah dasar agar selalu aktif berpartisipasi dalam pembelajara sehingga mendapatkan pengetahuan baru dari pengalaman belajar tersebut, serta mendapatkan hasil belajar yang maksimal. Ketiga, bagi peneliti lain yang akan mengadakan penelitian lebih lanjut model pembelajaran kooperatif tipe Course Review Horay agar memperhatikan kendala-kendala yang dialami dalam penelitian ini sebagai bahan pertimbangan untuk perbaikan dan penyempurnaan penelitian yang akan dilaksanakan.

\section{Daftar Rujukan}

Kharida, L.A. 2009. "Penerapan Model Pembelajaran Berbasis Masalah Untuk Peningkatan Hasil Belajar Siswa Pada Pokok Bahasan Elastisitas Bahan". Jurnal Pendidikan Fisika Indonesia. Volume 5, Nomor $83 . \quad$ Tersedia pada https://journal.unnes.ac.id/artikel_nju/JPFl/1015 (diakses pada 9 Januari 2018).

Kurniasih, Imas dan Berlin Sani. 2015. Ragam Pengembangan Model Pembelajaran. Cetakan Ke-3. Kata Pena.

Lianto, I.M. 2016." Pengaruh Model Pembelajaran Course Review Horay Terhadap Hasil Belajar IPA Siswa Kelas IV". E-Journal Mimbar PGSD, Volume 4, Nomor 1. Tersedia pada https://ejournal.undiksha.ac.id/index.php/JJPGSD/issue/view/119 (diakses pada 2 Mei 2018).

Maryam, Siti, Muh. Hasbi, Abd. Hamid. 2016. Jurnal Elektronik Pendidikan Matematika Tadulako, Volume 04 Nomor 01 Hal. 116-130. Tersedia Pada : http://jurnal.untad.ac.id/jurnal/index.php/JEPMT/article/view/7259.

Nahar, Arifatun Dwi Sulistyaningsih, Eko Andy Purnomo. 2016. Keefektifan Model Pembelajaran Course Review Horay dengan Pendekatan Kontekstual terhadap Kemampuan Komunikasi Matematis pada Materi Segitiga Kelas VII. JKPM, Vol. 3 No. 1, Hal. 48-58, Tersedia Pada : http: //jurnal.unimus.ac.id.

Permana, Kadek Martin Edi .2016. "Penerapan Metode Demonstrasi Dengan Pemanfaatan Media Batang Cuisenaire Untuk Meningkatkan Hasil Belajar Matematika Kelas III". ejournal Mimbar PGSD. Volume 4, Nomor 3. Tersedia pada https://ejournal.undiksha.ac.id/index.php/JJPGSD/article/view/6599/4499 (diakses pada 9 Januari 2018).

Sari, Diah Kumala. 2015. Efektivitas Model Pembelajaran Course Review Horay Berbantuan Handout terhadap Prestasi Belajar Peserta Didik Kelas X MA Ribatul Muta'allimin Kota Pekalongan. $\delta$ E L T $\Delta$ | Vol.3 No.1, Januari 2015, hlm 15-24. Tersedia Pada: https://jurnal.unikal.ac.id/index.php/Delta/article/view/439.

Sari, Made Indrieta. 2017. "Pengaruh Model Pembelajaran Course Review Horay Terhadap Aktivitas Dan Hasil Belajar Kognitif IPA Siswa Kelas V".e-journal Mimbar PGSD. Volume 5, Nomor $2 . \quad$ Tersedia pada https://ejournal.undiksha.ac.id/index.php/JJPGSD/article/view/11008 (diakses pada 9 Januari 2018).

Supriani, Ketut Rita. 2017. "Pengaruh Model Pembelajaran Kooperatif Tipe Course Review Horay Terhadap Keaktifan Dan Hasil Belajar IPA". e-journal Mimbar PGSD. Volume 5, Nomor

2. Tersedia pada https://ejournal.undiksha.ac.id/index.php/JJPGSD/article/download/10930/7006 (diakses pada 9 Januari 2018). 
Suwatra, Ign I Wayan, dkk. 2015. Belajar dan Pembelajaran Sekolah Dasar. Singaraja: Universitas Pendidikan Ganesha.

Triyanti, Merti, Harmoko, Nova Lestari. 2018. Efektivitas Model Pembelajaran Course Review Horay terhadap Hasil Belajar Biologi dan Motivasi Siswa Kelas X SMA Negeri Jayaloka. Bioedukasi VOL 9. NO 2 Hal. 99-108. Tersedia Pada : http://ojs.fkip.ummetro.ac.id/index.php/biologi/article/view/1605/1014. 